\title{
THE INTERPLAY BETWEEN THE UNFAIR COMMERCIAL PRACTICES DIRECTIVE AND CODES OF CONDUCT
}

\author{
C.M.D.S. Pavillon ${ }^{*}$
}

\begin{abstract}
At the heart of this paper lies the reciprocal influence between codes of conduct and the Unfair Commercial Practices Directive (UCPD). It assesses to what extent self-regulatory practice both affects and is affected by the directive. The codes' contribution to consumer protection has not sensibly increased since the directive took effect. Codes of conduct hardly flesh out the directive's general clauses and are still predominantly confined to help enforce the misleading clause. Codes of conduct also barely add to advancing the harmonisation goal of the directive. Their impact on the interpretation and enforcement of the directive's standards has been more constrained than stimulated by the UCPD and the way it is has been implemented at the national level. To increase self-regulation's share in the achievement of the consumer protection and harmonisation goals of the directive, the directive should be amended so as to strengthen the role of codes of conduct in the interpretation and enforcement of the UCPD standards. More co-regulation in the sense of a further integration of codes of conduct into the UCPD should however respect the delicate balance between consumers' and traders' interests.
\end{abstract}

Keywords: Unfair Commercial Practices Directive; self-regulation; codes of conduct; general clauses; European harmonisation; consumer protection.

\section{Introduction}

To prepare its Report on the application of the Unfair Commercial Practices Directive (UCPD) ${ }^{1}$ the Commission has invited stakeholders to fill in a questionnaire. In its enquiries about self-regulation of fair trading, the Commission focuses on the adherence to codes of conduct, the cooperation between self-regulatory bodies and public authorities, the enforcement of, and compliance to codes of conduct and the measures that were taken to stimulate self-regulation at the national level. This article intends to specify the impact study aimed at by the Commission by linking those phenomena and others, like the fairness and the development of new codes, to the directive itself and to how it deals with self-regulation. ${ }^{2}$

The UCPD aims at both a high and a common level of consumer protection so as to smoothen the functioning of the internal market. ${ }^{3}$ A high level of consumer protection enhances consumer confidence and a harmonised level of protection induces (small) businesses to participate in the internal market. This paper revolves around the question whether the UCPD allows for codes of conduct to help reach the directive's twofold goal. As such, it explores the interplay between the UCPD and codes of conduct regulating business-to-consumer (B2C) trade at EU level and in three Member States (MS). It assesses in how far codes of conduct both affect and are affected by the UCPD. Codes of conduct can potentially add to advancing the consumer protection and harmonisation

Dr. C.M.D.S. (Charlotte) Pavillon is a postdoctoral researcher with the Groningen Centre for Law and Governance, University of Groningen (The Netherlands).

Directive 2005/29/EC on unfair business-to-consumer commercial practices in the internal market (OJ 2005 L 149/22).

The UCPD only implicitly favours the co-regulatory approach: F. Cafaggi, 'Private Regulation in European Private Law', in A.S. Hartkamp et al. (eds.), Towards a European Civil Code (2011), at 119-120.

3 Recital 1 of the UCPD states that the European Community ought to contribute to the attainment of a high level of consumer protection. According to Recital 5, obstacles to the free movement of services and goods across borders or the freedom of establishment can only be eliminated by establishing uniform rules at European level, which establish a high level of consumer protection. Member States are not allowed to adopt more protective rules within the field approximated by the UCPD (Article 4). A high level of consumer protection is therefore subordinate to the harmonisation goal. 
goals of the directive by impacting both the interpretation and the enforcement of the directive's standards. This impact is however, to some extent, either constrained or stimulated by the UCPD itself and by the way it is implemented, interpreted and enforced. The purpose of this paper is to examine how the mutual relationship between private regulation and the UCPD can be optimised with a view on the interests of both consumers and traders.

The reciprocal influence between codes of conduct and the UCPD lies at the very centre of this analysis. Section 2 establishes how the foundation for this interplay was laid, that is, how codes were integrated into the UCPD. Section 3 delves into the influence codes of conduct exercise on the fairness assessment by public authorities and national courts, whereas section 4 takes a closer look at the enforcement of the UCPD by code owners. Both paragraphs evaluate how codes add to consumer protection while section 5 determines their contribution to harmonisation. All three paragraphs investigate how the directive allows for those contributions to be made. The paper focuses on two MS that have had comparable approaches to self-regulation at the time the UCPD took effect. The use of self-regulation as a complement to legislation is well known in the UK and in the Netherlands. The third MS under scrutiny has traditionally had a different approach to self-regulation. In France, codes of conduct are less common. Those resemblances and differences help determine both the increase and convergence in self-regulatory enterprise.

\section{The UCPD and Self-Regulation of Commercial Practices Directed to Consumers}

\subsection{The Commission's Initial Wish for European Codes of Conduct}

In the Green Paper that lit up the path towards the UCPD, the Commission considered self-regulation to be a potentially effective complement to regulation and wondered whether it would be useful to include a basis for self-regulation in a framework directive. The Commission also observed that self-regulation remained severely constrained at EU level because of the degree of national diversity. ${ }^{4}$ Outside the area of technical harmonisation, EU-wide self-regulation had not made much headway prior to the directive. EU instruments pertaining to commercial practices - notably in the field of distance selling ${ }^{5}$ and electronic commerce ${ }^{6}$ - had not proved very successful in promoting the development of Europe-wide codes of conduct. ${ }^{7}$ There were a few exceptions though. Mention can be made of Euro-Label, a European Electronic Trustmark based on an EU-wide code of conduct, which was created in 2002. In the field of advertising, ${ }^{8}$ the European Advertising Standards Association (EASA) has issued many guidelines and standards throughout the years. The Organisation for Timeshare in Europe (1998) even devised a Code of Ethics without being encouraged thereto by any EU instrument. ${ }^{9}$

Before the UCPD came into being, the Commission clearly expressed the wish EUwide codes would develop. In its Follow-up Communication to the Green Paper, the Commission uttered European codes of conduct should provide an "implicit "presumption of conformity" ' with the fairness standard. ${ }^{10}$ The Commission also announced it would consult further on whether there was a need to provide for endorsement of such codes.

\footnotetext{
Green Paper on EU Consumer Protection, COM(2001) final 531, at 2, 5 and 15.

Directive 97/7/EC on distance contracts (OJ 1997, L 144/19) and Recommendation 92/295/EC.

Directive 2000/31/EC on certain legal aspects of information society services, in particular electronic commerce (E-commerce Directive) (OJ 2000 L 178/1) and the e-Confidence initiative (May 2000).

Consumer Confidence in e-commerce: lessons learned from the e-confidence initiative SEC (2004)1390, at 7-8. The codes of conduct issued by the Federation of European Direct and Interactive Marketing (FEDMA) and the European Direct Selling Association (Seldia) stem from before the E-commerce Directive.

8 Directive 84/450/EEC on misleading advertising (OJ 1984, L 250/17).

9 Directive 94/47/EC on timeshare (OJ 1994, L 280/83) does not promote self-regulation.

10 Follow-up Communication to the Green Paper on EU Consumer Protection, COM (2002) final 289, at 11.
} 
None of these wishes and intentions have however materialised in the UCPD. The potential role of self-regulation in tackling unfair commercial practices and overcoming national legal diversity has been strongly reduced during the negotiations on the UCPD. The next paragraphs analyse what was left of the references to self-regulation and codes of practice in the directive.

\subsection{Codes of Conduct: A Potential Evidence of (Un-)Fairness?}

\subsubsection{Compliance with a code}

The general fairness clause is built upon two concepts. According to Article 5(2) UCPD an unfair commercial practice is

contrary to the requirements of professional diligence

and

materially distorts or is likely to materially distort the economic behaviour with regard to the product of the average consumer whom it reaches or to whom it is addressed, or of the average member of the group when a commercial practice is directed to a particular group of consumers.

The professional diligence requirement is defined in Article 2(h) as

the standard of special skill and care, which a trader may reasonably be expected to exercise towards consumers, commensurate with honest market practice and/or the general principle of good faith in the trader's field of activity.

Public authorities must test the trader's behaviour or conduct against this legal standard. The professional diligence requirement is founded on a combination of customary and normative criteria. The normative criteria ensure that the business community does not itself determine the minimum content of the honest market practice standard. In the build-up to the UCPD, the Commission relinquished the regulatory technique consisting of offering codes of conduct the status of 'safe harbour' (like the 'New Approach' to technical standards). ${ }^{11}$ Under the directive, compliance with a code of conduct does not entail (virtual) immunity against the charge of unfair commercial practice. It does not even lead to a 'presumption of conformity' with the legal standard. It has been suggested that a presumption of conformity would not be feasible for codes of conduct anyway, since compliance with the open-textured standards of a code cannot easily be measured and controlled. ${ }^{12}$

Not even codes that were devised in consultation with consumer organisations or approved by a relevant public authority are presumed to be fair. There are no provisions that lay down criteria 'fair' codes of conduct would have to meet. Neither are there any directive provisions that tackle unfair codes as such (whilst the trader subscribing to the code would himself be immune from legal challenge). The directive does not hold accountable a trade association that devises a code that promotes or contains unfair practices. It leaves it to each MS to decide whether legal facilities may be directed against a code owner ${ }^{13}$ where the relevant code promotes non-compliance with legal requirements (Article 11(1) paragraph 2(b)). The Commission thereby meant to avoid the risk that trade associations would become reluctant to draft codes. ${ }^{14}$

11 H. Collins, 'EC Regulation of Unfair Commercial Practices', in H. Collins (ed.), The Forthcoming EC Directive on Unfair Commercial Practices (2004), at 30.

${ }_{12}$ H.-W. Micklitz, 'A General Framework Directive on Fair Trading', in H. Collins (ed.), The Forthcoming EC Directive on Unfair Commercial Practices (2004), at 83-84.

13 A code owner is any entity, including a trader or group of traders, which is responsible for the formulation and revision of a code of conduct and/or for monitoring compliance with the code by those who have undertaken to be bound by it (Article $2(\mathrm{~g})$ ).

14 Collins (2004), above n. 11, at 31. 
Compliance with a code (and definitely with a publicly approved, widely established code ${ }^{15}$ nevertheless provides strong evidence of compliance with the duty to trade fairly. This is laid down in recital 20 of the preamble to the directive. ${ }^{16}$ The Court of Justice of the European Union (CJEU) has not yet provided for an autonomous interpretation of the professional diligence requirement but the Commission Guidance states that high standards, which are widely supported and largely complied with, "may be a useful term of reference for national authorities and courts in assessing whether, in a concrete case, a commercial practice is unfair' ${ }^{17}$ Although compliance with a code does not constitute a formal guarantee for passing the 'professional diligence' test, a marketbased interpretation of the fairness clause laying the emphasis on the customary criteria is likely to prevail. Such an interpretation may allow for codes of conduct to provide conclusive evidence as to the requirements of professional diligence in a specific sector. The decision to impose stricter standards would have to be duly motivated.

\subsubsection{Non-compliance with a code}

Compliance with a code of conduct may well not exonerate the trader, but non-compliance does inversely not automatically incriminate him. A trader failing to comply with a code of conduct he has not adhered to will not necessarily breach the requirements of professional diligence. This trader might still behave in accordance with honest market practices. Codes are not subjected to full harmonisation and may reflect more stringent views on what the fairness standard entails. They might follow a very consumer-friendly interpretation of the legal standards or even set higher standards. The purpose of most codes of practice is to set out good trading practices towards consumers that exceed legal requirements. Requiring traders to follow the most demanding standards would however have anti-competitive effects. ${ }^{18}$ Code owners are allowed and even spurred to raise the level of protection required by the UCPD. The UK's Office of Fair Trading (OFT) for example only approves and promotes codes that are shown to safeguard and promote consumers' interests beyond the basic requirements of the law. ${ }^{19}$ Still, a trader who fails to comply with a code of conduct by which he has undertaken to be bound is under specific conditions committing an unfair practice (Article 6(2)(b), cf. paragraph 2.3.1 and 4.4.3) ${ }^{20}$ The UCPD places the emphasis on the honest use of codes of conduct rather than on the codes' content.

\subsection{The Honest and Responsible Use of Codes of Conduct}

\subsubsection{Voluntary codes bind signatories}

The provision forcing respect for codes of conduct is the farthest-reaching of the directive provisions interfering with self-regulation. The non-compliance by a trader with a code of conduct to which he has adhered constitutes a misleading practice and is therefore prohibited (Article 6(2)(b)):

A commercial practice shall also be regarded as misleading if, in its factual context, taking account of all its features and circumstances, it causes or is likely to cause the average consumer to take a transactional decision that he would not have taken otherwise, and it involves:

\footnotetext{
15 Ch. Twigg-Flesner et al., An Analysis of the Application and Scope of the Unfair Commercial Practices Directive. A Report for the Department of Trade and Industry (2005), at 8 (§ 2.16). Arguably, the involvement of stakeholders into the drafting of codes would confer legitimacy upon them.

16 Cf. also the Explanatory Memorandum to the draft directive, COM (2003) 356 final, at $\S 73$.

17 Guidance on the implementation/application of directive 2005/29/EC on unfair commercial practices, SEC(2009) 1666, at 20.

${ }_{18}$ Twigg-Flesner et al. (2005), above n. 15, at 8 (§ 2.16).

19 The OFT has been empowered to endorse codes of conduct meeting core criteria since 2002.

20 The misleading claim to abide by a code requires the trader to have undertaken to be bound by this code. The trader does not need to have actually signed up to the code.
} 
(b) non-compliance by the trader with commitments contained in codes of conduct by which the trader has undertaken to be bound, where:

(i) the commitment is not aspirational but is firm and is capable of being verified, and

(ii) the trader indicates in a commercial practice that he is bound by the code.

In its Green Paper, the Commission stressed the benefits of such a provision. ${ }^{21}$ From the consumers' point of view, the advantage of more rigorously enforced voluntary commitments is the increased confidence that public enforcement bodies would act as the 'enforcer of last resort'. By reinforcing the control exercised by the code owners themselves, this Article could provide a stronger case for less substantive regulation, which is beneficial for traders. More rigorous self-regulation could also tackle the 'free rider' problem, by providing an additional point of reference for courts and enforcement authorities in confronting traders outside such agreements.

This misleading practice has, however, principally been regarded as a disincentive for voluntary adhering to a code of conduct. Although this Article may add to an effective self-regulatory system by protecting consumers against traders who misleadingly advertise with the membership of a code, it puts a signatory trader at risk as a 'challenge to its marketing practices could be successful on a technical non-compliance with some detailed provision of a code'. ${ }^{22}$ 'A technical non-compliance with some detailed provision of a code' may however not always have a significant effect on the average consumer's economic behaviour, depending on the content of the obligation imposed by the provision in question. That being said, there is a risk that unintended non-compliance - a trader misjudging his obligations - would amount to a misleading practice, the Article not being limited to situations where the trader deliberately breaches a code.

Article 6(2)(b) is concerned with striking a balance between the voluntary character of a code and the confidence it raises amid consumers. Consumers should be protected without traders being discouraged from adhering to a code. The commitment the trader failed to live up with must be firm and capable of being verified afterwards. The distinction between a firm and an aspirational commitment is however a blurred one. ${ }^{23}$

\subsubsection{Forbidden false claims about codes and marks}

The list of commercial practices that are under all circumstances deemed unfair provides further support for the honest use of codes of conduct and trust marks. The following practices are forbidden because of their flagrantly misleading nature (Annex 1):

1. Claiming to be a signatory to a code of conduct when the trader is not.

2. Displaying a trust mark, quality mark or equivalent without having obtained the necessary authorisation.

3. Claiming that a code of conduct has an endorsement from a public or other body which it does not have.

Those provisions ensure that traders make responsible use of codes of conduct in their marketing activities. The black list seems to have a deterrent effect. There are hardly any administrative or court decisions regarding the black list provisions relating to selfregulation yet. ${ }^{24}$

21 Green Paper, above n. 4, at 14.

22 Collins (2004), above n. 11, at 31.

23 G. Howells, 'Codes of conduct', in G. Howells, H.-W. Micklitz and T. Wilhelmsson (eds.), European Fair Trading Law: The Unfair Commercial Practices Directive (2006), at 208.

24 I have found one example of a breach of point 1 of Annex 1 - a trader making false claims about its credentials (Anna Tillman) - and one example of a breach of point 2 - Displaying an unauthorised trustmark or equivalent (Bradley's Fine Jewellery Ltd) - being tackled by the trading standards in the UK. 


\subsection{The Recourse to Self-Regulatory Bodies}

The legal regime of the UCPD is largely based on enforcement through courts and administrative authorities. Codes of conduct are voluntarily accepted rules and are supplementary to both legislation and jurisprudence. Articles 10 and 11(1) define the role of self-regulation in controlling unfair practices. Article 10 is 'not overly friendly towards codes' ${ }^{25}$ Although self-regulation cannot replace judicial or administrative recourse, MS may encourage the recourse to self-regulatory bodies in addition to court or administrative proceedings. This provision does not oblige MS to stimulate control of unfair commercial practices by code owners, nor does it require them to foster the development of codes (unlike the E-commerce Directive). Article 11(1) goes a little further in encouraging reliance on codes. It enables MS to decide whether to enable the courts or administrative authorities to require prior recourse to 'other' established means of dealing with complaints, including those referred to in Article $10{ }^{26}$ Finally, Article 17 asks MS, where appropriate, to encourage traders and code owners to inform consumers of their codes of conduct.

\subsection{The UCPD and Self-Regulation: All Stick and No Carrot?}

Codes were very cautiously brought into the UCPD, which does not provide many incentives for private actors to develop new self-regulatory mechanisms either at national or EU level. There are no binding requirements guiding the content of the codes or the right of consumers to participate into their drafting. No privileges were granted to those who voluntary comply with a non-binding code. Codes are neither 'safe harbours' nor presumed to be in conformity with the UCPD, even if they have been publicly endorsed. Codes may guide the fleshing out of the general clauses but this is left to those applying them. Compliance with a code may therefore not add real value. Adhering to a code even increases the risk to be found guilty of a misleading practice. According to the European Association of Communication Agencies, the UCPD expresses a bias against self-regulation threatening existing self-regulatory regimes instead of stimulating them. ${ }^{27}$

The way the UCPD is being enforced and interpreted at the national level may however have had a stimulating impact on codes of conduct's share in the achievement of the consumer protection and harmonisation goals of the directive. ${ }^{28}$ The interplay between the UCPD and codes of conduct will be assessed through an analysis of Dutch, French and English case law and self-regulatory practice. The UCPD has been transposed in the Civil Code in the Netherlands, in the Consumer Code in France and in the Consumer Protection from Unfair Trading Regulations 2008 in the UK (CPR 2008).

\section{Codes of Conduct's Contribution to Consumer Protection as a Benchmark of Fairness}

\subsection{Codes of Conduct as a Benchmark of Fairness}

Even though compliance with voluntary codes of conduct does not provide traders with a 'safe harbour' or a presumption of conformity, the administrative bodies and the judiciary may have decided otherwise and viewed compliance with a code of conduct as an evidence of fairness. Codes are however expected to prove more successful

\footnotetext{
25 Howells (2006), above n. 23, at 211.

26 Established means are well-founded and effective systems of regulation (including self-regulation).

27 Position Paper of the European Association of Communication Agencies, 15 November 2003.

28 It goes without saying that the increase of self-regulatory practice depends on more factors than the legal status of codes of conduct such as the need and the willingness to ban rogue traders from the market and to prefer 'fair' regulation above minimum standards which are cheaper to comply with: Collins (2004), above $\mathrm{n} .11$, at 32 . This paper however focuses on the interplay between the law and self-regulation.
} 
in providing evidence that a practice is unfair than in establishing its fairness. It is indeed more acceptable for code owners to set the 'minimum standards' consumers may reasonably expect than 'to set a cap on what the law accepts' ${ }^{29}$ Since under the directive, private bodies may apply their own higher standards ${ }^{30}$ and are most likely to do so, codes will nonetheless generally entail everything but a minimum standard. ${ }^{31}$ The emphasis being put on non-compliance may discourage self-regulation. It would however secure the high level of consumer protection aimed at by the UCPD.

As the Commission predicted ${ }^{32}$ administrative bodies and courts rarely need to resort to the general clause and the professional diligence requirement laid down in Article 5(2) UCPD. ${ }^{33}$ This general clause operates as a safety net, the smaller general clauses covering most unfair commercial practices. However, even though the definitions of misleading and aggressive practices do not entail a separate reference to the professional diligence test ${ }^{34}$ codes of conduct may also be relevant to the assessment of such practices. ${ }^{35}$

\subsection{Codes of Conduct as a Benchmark of Fairness in France}

According to Article 2(h) UCPD, the professional diligence requirement of the general fairness clause encompasses both customary ('standard of special skill and care', 'market practice') and normative criteria ('honest', 'good faith'). By failing to transpose this definition, French law keeps the normative dimension of the professional diligence requirement out of the courts' sight. The reason why this definition has been left aside is not clear as it was not explicitly motivated during the transposition process. ${ }^{36}$ Although the lack of visibility of the objective normative bearing of the requirement could have led to a market-based interpretation of the criterion, it hasn't. As it turned out, French courts have shown a certain willingness to interpret French law in conformity with the Directive. ${ }^{37}$

The French Direction Générale de la Concurrence, de la Consommation et de la Répression des Fraudes (DGCCRF) - the public body in charge of the enforcement of the UCPD - acknowledges that codes of ethics common to licensed (self-employed) professionals in the field of law and medicine and the codes of conduct drawn up by the Distant and Direct Selling Federations help inform the content of the professional diligence requirement, alongside with trade usage. ${ }^{38}$ The DGCCRF however sees the professional diligence test as a broader test, which is relying on normative concepts as well.

In France, different commercial practices formerly prohibited by the Consumer Code must now be reviewed under the general clause laid down in Article L 120-1 Consumer Code before being condemned. The tied sale practice once banned by Article L 122-1

29 Howells (2006), above n. 23, at 213.

30 The UCPD, which is based on maximum harmonisation, only effectively provides for minimum harmonisation of codes of conduct.

31 G. Howells, 'Co-Regulation's Role in the Development of European Fair Trading Laws', in H. Collins (ed.), The Forthcoming EC Directive on Unfair Commercial Practices (2004), at 122.

$32 \operatorname{COM}(2003) 356$ final, above n. 16, at $\$ 52$ and 56.

33 As far as I know, only one action taken by a trading standard has been solely based on the general prohibition (Norman Coutts). Enforcement authorities in both the UK and the Netherlands regularly establish the breach of the general clause on top of the breach of the smaller clauses. This however holds the risk that legal action is instituted twice for the same cause of action.

34 As the Commission puts it: 'Misleading a consumer or treating them aggressively are considered in themselves to be distortions of consumer behaviour rather than legitimate influence and, as such, contrary to the requirements of professional diligence': COM(2003) 356 final, above n. 16, at $\S 57$.

35 Howells (2006), above n. 23, at 213.

36 XIIIo législature/Assemblée Nationale (No 408), 14 November 2007, at 55-56 mentions this choice but does not explain it.

37 C.M.D.S. Pavillon, Open normen in het Europees consumentenrecht: de oneerlijkheidsnorm in vergelijkend perspectief (2011), at $\$ 567$ and 589.

38 DGCCRF note No 2009-07, 29 January 2009. Cf. INC Hebdo No 1497, 1 December 2008. According to the National Consumer Institute professional diligence refers to the norms which are generally accepted within the sector of activity, that is the 'habits and customs' of the professional branch in question. Those rules can be found in codes of ethics. 
Consumer Code has been tested against the general clause on many occasions, with different outcomes. ${ }^{39}$ When fleshing out the professional diligence criterion, ${ }^{40}$ French courts rely on normative viewpoints, technical aspects and current market practice. ${ }^{41}$ Self-regulation - regarding for instance the sale of computers with pre-installed software - does not help fill in this criterion for the simple reason that it does not exist. ${ }^{42}$

Self-regulation of marketing standards is not well developed in France and does not have much impact on the fairness assessment. As for the misleading clause, exceptions exist, though. The case wherein a French price comparison website was accused of misleading and unfair commercial practices as it did not warn the consumer about its advertising nature makes that clear. The website was found to breach the Charte des sites Internet comparateurs it had subscribed to. ${ }^{43}$ This was considered a misleading practice within the meaning of Article 6(1) UCPD. ${ }^{44}$

\subsection{Codes of Conduct as a Benchmark of Fairness in the Netherlands}

The Dutch provision implementing the definition of the professional diligence requirement - Article 193a(1)(f) of Book 6 of the Civil Code - initially lacked the normative criterion and it still does not comprise the good faith notion. Besides, the legislator has, in his explanatory documents, underlined the relevance of codes of conduct to this requirement, especially when consumer associations have been involved. ${ }^{45}$ The provision, in its final version, refers to 'honest market practices' and Dutch scholars have stressed the normative nature of the professional diligence requirement. ${ }^{46}$

For now, the main Dutch public authority in charge of the enforcement of the $\mathrm{UCPD}^{47}$ - the Consumer Authority (CA) - has concretised the professional diligence requirement only by referring to codes of conduct. ${ }^{48}$ In two separate cases, it considered the requirement was breached because the trader had failed to abide by the standard of conduct laid down in a code. The CA even alluded to codes of conduct the trader under investigation had not subscribed to; reckoning those codes still defined the minimum standard of conduct that could be reasonably expected from traders in the energy sector. In its decision concerning the Nederlandse Energie Maatschappij (NLE) the breach of the requirement of professional diligence was not only assessed in reference to the Consumer and Energy Supplier-Code the trader signed up to, but also to the Telemarketing Code and the Currence Rules \& Regulations, two codes the NLE had not adhered to. In an appeal procedure before the Rotterdam Court of First Instance, the NLE defended itself by arguing that it was not bound by the Currence rules, that these rules should not define the level of professional diligence it ought to attain and that legal

39 Cf. $\operatorname{COM}(2003) 356$ final, above n. 16, at $\S 50$; Pavillon, above n. 37, at $\S 606$.

40 Courts do not always pay attention to this criterion: CA Paris 14 May 2009, No 09/03660, Dalloz 2009, at 1475

41 JProx Lorient 27 August 2009, No 91-08-000276; C. Cass. 13 July 2010, No 09-15304 and 09-66970; C. Cass. 12 July 2012, No 11-18807.

42 Some MPs have unsuccessfully tried to codify a duty to inform the consumer about the separate prices of both the computer and the software in 2008: traders are therefore not under pressure to regulate their own practices.

43 CA Grenoble 21 October 2010 (Kelkoo), No 08/03251 followed by C. Cass. 29 November 2011, No 10-27402.

44 In another case, wherein a B2B commercial practice was held misleading under the UCPD-clause, a reference was made to the infringement on both a recommendation of the Autorité de Régulation Professionnelle de Publicité and the consolidated International Chamber of Commerce (ICC) code of advertising and marketing communication practice: CA Paris 8 November 2011, No 11/16050.

45 Dutch Parliamentary Papers 2006/2007, 30928, No. 3, at 16-17.

46 M.F.H. Broekman, 'De Richtlijn Oneerlijke Handelspraktijken', Tijdschrift voor Consumentenrecht 5, at 180 (2005); W.H. van Boom, 'Inpassing en handhaving van de Wet oneerlijke handelspraktijken', Tijdschrift voor Consumentenrecht en Handelspraktijken 1, at 4 (2008); D.W.F. Verkade, Oneerlijke handelspraktijken jegens consumenten (2009), at § 26.

47 Together with the Dutch Financial Markets Authority (AFM).

48 Celldorado (case 510, 17 June 2010) at $\$ 333$ f followed by CFI Rotterdam 19 April 2012, LJN BW3358 and Nederlandse Energie Maatschappij (case 527, 6 September 2010), at $\S 308$ followed by CFI Rotterdam 12 November 2010, LJN BO3707, at § 2.3.2. 
certainty was at stake. ${ }^{49}$ The Administrative Court declared the CA was right to found its decision on the Currence rules. In the domain of public enforcement of the UCPD, code of conducts largely set the professional diligence standard. ${ }^{50}$

In the Celldorado-case, which concerned unfair SMS practices, the Administrative Court however emphasised the factual and normative dimension of the professional diligence test and the necessity to test the trader's behaviour against the legal standard. ${ }^{51}$ It has stated that acting in compliance with a code does not automatically amount to fair conduct in the sense of the UCPD and that the standard laid down in a code can diverge from the legal standard. The SMS services providers pretended they had been found guilty of unfair practices while complying with the SMS-Code of Conduct. Their and, allegedly, ${ }^{52}$ the code owner's interpretation of the code diverge from the interpretation conferred by the CA on the broadly worded commitments laid down in the SMS-Code. Compliance or non-compliance with the open-textured standards of a code of conduct cannot easily be measured and requires public bodies to interpret the private standard. Defining the level of professional diligence therefore comes down to the interpretation of a code of conduct by the public enforcement body. The CA interprets codes in a consumer-friendly way but does not explicitly ascertain how the code itself relates to the legal standard.

\subsection{Codes of Conduct as a Benchmark of Fairness in the UK}

In the UK, the professional diligence requirement has been brought in relation to the common law concepts of 'due diligence' and 'due care' ${ }^{53}$ on which is based the 'standard of (reasonable) care'. ${ }^{54}$ This standard is fixed by 'current market practice', ${ }^{55}$ that is, a 'practice common to a reasonable body of opinion'. ${ }^{56}$ During the transposition process, the UK government stated that in 'regulated sectors like financial services [the requirement of professional diligence was] likely to equate to compliance with existing regulation and conduct of business rules'.57

As of today, the 'standard of care/due diligence' has however not impacted the interpretation of the UCPD. The traditional inclination to self-regulation has not yet been reflected in the way the professional diligence requirement is being enforced by the courts or the OFT. Codes are not being referred to and OFT approved codes do not give 'safe harbours' from potential OFT action. ${ }^{58}$ The OFT has however not yet taken any action against a trader who has subscribed to an approved code and the professional diligence requirement has only been (briefly) mentioned once by the judiciary. ${ }^{59}$

\footnotetext{
49 CFI Rotterdam 12 November 2010, LJN BO3707, at § 2.2.3.

50 In CFI Amsterdam 18 May 2011, LJN BQ6506, a civil court established the breach of the professional diligence requirement without any reference to self-regulatory instruments.

51 CFI Rotterdam 19 April 2012, LJN BW3358, at $\S 21.5$ and $\S 23.2-3$.

52 Opinion of the Adviescommissie bezwaarschriften (BAC) of the Dutch CA in the Celldorado-case (case 510, 7 December 2010), at § 5.20: <www.consumentenautoriteit.nl/sites/default/files/redactie/CANB-510-86.openbaar\%20advies\%20BAC\%20v2_0.pdf> (last visited on 18 September 2012). The trader failed to substantiate this argument: CFI Rotterdam 19 April 2012, LJN BW3358, at § 23.3.

53 G.B. Abbamonte, 'The Unfair Commercial Practices Directive and its General Prohibition', in S. Weatherill and U. Bernitz (eds.), The Regulation Of Unfair Commercial Practices Under EC Directive 2005/29: New Rules And New Techniques (2007), at 22.

54 Bolam v. Friern Hospital Management Committee [1957] 1 WLR 582.

55 M. Griffiths, 'Unfair commercial practices. A new regime', 12 Communications Law 6, at 198 (2007).

56 Twigg-Flesner et al. (2005), above n. 15, at 6.

57 Government Response to the Consultation on an EC directive on Unfair Business-to-consumer Commercial Practices in the Internal Market (March 2004), at 3.

58 Policy Statement on the role of self-regulation in the OFT's consumer protection work (September 2009), at $§ 2.8$.

59 The Office of Fair Trading v Ashbourne Management Services Ltd \& Ors [2011] EWHC 1237 (Ch) (27 May 2011).
} 


\subsection{The Balance of Interests}

Self-regulation has not given much impact on the interpretation and enforcement of the fairness clause. Codes of conduct barely flesh out the directive's general clause, mainly because the professional diligence requirement is not applied very often (UK) but also because such codes are not available (France). They do not play any significant concretising role with regard to the smaller general clauses either (except for Article 6(2)(b), cf. paragraph 4.4.3). Codes of conduct have however informed the content of the professional diligence requirement in the domain of public enforcement in the Netherlands. Codes have then proved more successful in providing evidence that a practice is unfair than in proving fairness. No trader has to my knowledge yet been discharged because his conduct was in accordance with a code. ${ }^{60}$

The emphasis on non-compliance is beneficial for the consumer. This approach, which supposedly is influenced by Article 6(2)(b), however potentially harms the trader's interests. In the Netherlands, codes have even been applied by analogy to nonmembers. It does not look like the possibility was examined that the standards laid down in the codes were too demanding. Using codes as a point of reference in tackling traders outside such agreements helps solving the free rider-problem, but a trader failing to comply with a code of conduct may not breach the requirement of professional diligence if this code prescribes a level of protection that is higher than the directive's maximum level. The risk of binding traders to professional standards that are too high in respect of the directive's level of protection is further increased by the consumer-friendly interpretation the CA gives to the codes it firmly holds on to. Because of its numerous general clauses and the lack of guidance from the CJEU, it however proves impossible to define the directive's level of protection with exactitude and thus to establish whether the threshold is set too high.

\section{Codes of Conduct's Contribution to Consumer Protection: The Enforcement of the UCPD by Code Owners}

\subsection{Three Conditions}

Private enforcement of the UCPD requires that codes of conduct are devised, which traders sign and live up to (paragraph 4.2). It also demands that self-regulatory bodies ensure the fairness of their codes (paragraph 4.3) and enforce them effectively, in conformity with the directive (paragraph 4.4). Effective self-regulation that contains firm commitments towards consumers can reduce the need for detailed legislation and administrative and judicial enforcement action. ${ }^{61}$ The effective enforcement of the UCPD by code owners requires codes to contain the standard set by the UCPD as a minimum ${ }^{62}$ and the possibility for code owners to enforce their codes by means of ex-ante tools (aiming at prevention) and/or ex-post schemes (aiming at redress). This possibility, however, is not sufficiently being supported by the directive.

\subsection{The Devising of New Codes}

Codes of conduct not being formally awarded a 'safe harbour'-status was expected to have a counterproductive effect on self-regulation and 5 years after the UCPD took effect, a code has, in a formal enforcement procedure, never served as a shield. A further disincentive for traders is the directive provision deeming a breach of a code a

\footnotetext{
${ }^{60}$ It is plausible that public bodies rather spare traders whose conduct is not (clearly) out of sound with the code they adhered to.

61 Self-regulation also reduces enforcement costs for consumers. Many consumers cannot afford the time, expense and anxiety of taking a case to court (if this is even possible under national law) and therefore fail to exercise their legal rights.

62 EP, DG for Internal Policies, Misleading Advertising on the internet (July 2010), at 17.
} 
misleading practice (Article 6(2)(b)). The Polish advertising self-regulatory body has for example stated that some businesses have become reluctant to sign up to a code after the implementation of the UCPD. ${ }^{63}$

The rigorous public enforcement of the UCPD standards may nevertheless have fostered self-regulation, spurring traders to establish codes of conduct that incorporate those standards. The day-to-day enforcement of the directive primarily falling to public authorities explains why there have been only few court decisions pertaining to the UCPD. Actions by the French DGCCRF and regional public bodies are less visible than the actions by the British and Dutch public enforcement authorities. The implementation and enforcement of the UCPD in France seems not to have had any significant effect on French self-regulatory practice anyway since new initiatives have been rare. Recent initiatives are confined to those fields where self-regulation had already been induced by 'older' sectoral directives, such as the directives on advertising and e-commerce. ${ }^{64}$

In the two MS where the UCPD is visibly being enforced by public authorities, new codes have been devised under pressure of those authorities after the directive took effect. ${ }^{65}$ The UCPD is only one of the many regulations public authorities are responsible of enforcing though. Those new codes were induced by the continuous failure to live up to different legal regulations. The UCPD has not in itself been a great impulse towards more self-regulation of $\mathrm{B} 2 \mathrm{C}$ commercial practices at the national level. This may partly be imputed to the general nature of the directive, which was designed as a framework directive. Sector-specific directives have had a greater impact on self-regulation. ${ }^{66}$ In the field of advertising, national self-regulatory bodies already existed in most MS. In various fields of activity, many codes of conduct in place in the UK and the Netherlands preceded the UCPD. The UCPD has not added much to the already existing European legal incentives for self-regulation.

Neither, unsurprisingly, has the directive changed the way self-regulation takes place. The Dutch process of self-regulation entails above all a dialogue between business and consumer organisations that gives rise to bipartisan general terms and conditions (GTC). The self-regulatory consultation coordination group of the Dutch Social and Economic Council provides for procedural rules and expertise but is itself not a party to the agreement. This two-sided form of self-regulation is still underdeveloped in Europe. In the Netherlands, the number of bilateral sets of GTC has increased over the years but this development can hardly be linked to the enforcement of the UCPD. ${ }^{67}$ The bilateral GTC dictate commercial conduct and describe many commercial practices. Public enforcers see them as codes of conduct. ${ }^{68}$ They however lack a number of commitments that characterise codes of conduct such as standards of service and advertising guidelines.

Finally, the UCPD failed in fostering new European initiatives. No new EU-wide codes of conduct regarding unfair B2C commercial practices have been devised since the directive was enacted. ${ }^{69}$

\footnotetext{
63 EP, DG for Internal Policies, State of play of the implementation of the provisions on advertising in the unfair commercial practices legislation (July 2010), at 20. Non-compliance with a code being put level with a breach of the requirement of professional diligence by the Dutch CA, regardless of the trader being a signatory, has however not evidently affected Dutch self-regulatory practice for the moment being, either negatively - by putting off potential signatories - or positively - by reducing the free-rider problem.

${ }^{64}$ A code of conduct pertaining to the e-sales of electrical and electronic devices was recently devised by, among other trade associations, the FEVAD (e-commerce and distant selling): <www.fevad.com/uploads/ files/Publications/Guide_bonnes_pratiques_ecommerce_251011.pdf $>$ (last visited on 18 September 2012). ${ }_{65}$ Cf. the Code of Conduct of the European Union Secondary Ticketing Association (2009), the SMSAdvertising Code (2009) and the Uneto-VNI Code of Conduct on Sale Guarantees (2012) in the Netherlands and the Code of Conduct of the Home Builders' Federation (2010) in the UK. There are still sectors left where a code of conduct is direly needed: the Dutch Competition Authority recently made an urgent call to comparison websites to devise a code.

${ }_{66}$ The enforcement of the Doorstep Selling Directive has had a major influence on the Dutch Consumer and Energy Supplier-Code which has been devised in 2006 under pressure of public authorities.

67 We can at least conclude that the cases within which traders were fined for breaching Article 6(2)(b) (cf. para. 4.4.3) have not yet discouraged trade associations of taking part in the dialogue.

68 CFI Rotterdam 12 November 2010, LJN BO3707, at § 2.2.3.

69 Recently seven national e-commerce associations created the E-commerce Association Europe (EAE). Their mission and goals however do not state anything about a European code of conduct or trustmark.
} 


\subsection{Fair Codes}

\subsubsection{Bringing codes of conduct in conformity with the UCPD}

Based on Article 10 UCPD, MS may, in addition to ensuring effective enforcement of the directive (as required by Article 11), encourage the control exercised by code owners on unfair commercial practices. Code owners can only exercise this control as long as their codes are attuned to the directive's standards. Moreover, a code can only serve as a benchmark of fairness to courts applying the UCPD provided its content can be deemed 'fair'. The fairness of a code of conduct hinges on the extent to which national code owners have internalised the UCPD standards. The scope of the general duty applies to trade associations and other organisations that make recommendations on trading practices and draw up codes.

The UCPD has broadened the standards by which commercial practices are judged. ${ }^{70}$ The UCPD obviously affects advertising rules and information duties most but all the practices that influence the consumer's ability to make an informed decision about a commercial transaction (before, during and after the conclusion of a contract) must at least match the UCPD standard. ${ }^{71}$ So, after-sales practices, complaint handling schemes and warranties have to fit the legal standard. This standard, however, is vaguely-worded and the directive's open-textured nature makes compliance uncertain. ${ }^{72}$ The formulation of some of the commitments laid down in a code can be as vague as the directive itself. ${ }^{73}$ The available guidance (including that issued by the Commission) and case law do not prevent diverging interpretations.

Many national and European codes of conduct that focus on B2C commercial practices at the national and European level have integrated the directive provisions. ${ }^{74}$ There is considerable variation in the way and extent to which the UCPD norms are being internalised by code owners. Some codes of conduct include a general duty to trade fairly (e.g. some codes that were approved by the OFT) or a prohibition on misleading practices (most advertising codes). ${ }^{75}$ In the field of advertising, self-regulatory bodies have been keen to ensure compliance with the UCPD misleading clauses ${ }^{76}$ Another way for code owners to implement the directive's standards is to lay down the obligation to interpret the code in conformity with the directive. ${ }^{77}$

The 'transposition' of the UCPD into codes of conduct is often less visible and does not consist of the transcription of the directive's general clauses. Some sectoral codes put down rules that (supposedly) meet the directive's standards, such as comprehensive

\footnotetext{
70 Most of the behavioural norms laid down in the UCPD, however, already applied to traders or at least embrace more specific norms that could effectively be enforced (under the Doorstep Selling Directive for example) and had been processed in existing codes.

71 A code may provide for a higher level of protection than the UCPD.

72 The level of protection imposed by the directive is not clear-cut as general clauses offer room for diverging appreciations.

73 Article 2.1 of Seldia's code of conduct towards consumers and Article 3(a) of the Code of Practice for consumers of the UK Direct Selling Association stipulate that direct sellers shall 'not use misleading, deceptive or unfair practices'. Article 1 of the Code of Practice of the British Association of Removers (BAR) obliges trader to act 'fairly and responsibly'.

74 Codes and recommendations pertaining to direct and distance marketing contributed to implementing the UCPD in Europe as show the European Code of Conduct towards consumers drafted by Seldia (cf. Article 2.12) and the EASA Best Practice Recommendation on Online Behavioural Advertising.

75 Cf. above n. 73.

76 The Dutch Stichting Reclame Code has implemented the UCPD long before the directive was implemented into Dutch law. In the UK, the Broadcast Committee of Advertising Practice (BCAP) carried out a consultation in July 2008 on proposed changes to bring the codes entirely into line with the new requirements set out in the CPR 2008. The CAP-code - the non-broadcast arm of the ASA, is based on ICC codes and has been updated to reflect the requirements of the new consumer regulations. The ICC itself integrated the UCPD into its codes.

77 The Irish Commission for Communications Regulation devised a Code of Practice for Premium Rates Services stating the practices it lies down 'are to be interpreted and understood in light of the provisions of the Unfair Commercial Practices Directive'.
} 
information duties and 'fair' promotional practices. ${ }^{78}$ Many codes do not literally transpose nor expressly refer to the UCPD. This is a reason why enforcement agencies refrain from establishing equivalence between codes of conduct and the UCPD when it comes to defining fair behaviour. ${ }^{79}$ In some MS, advertising bodies still do not cover all commercial practices accommodated by the UCPD. The Austrian and German codes for instance lack a broad concept of unfair commercial practices. The Austrian code does not even include 'misleading' advertising. ${ }^{80}$

The directive's enactment has indeed not led to the spontaneous adjustment of all existing codes. ${ }^{81}$ The Dutch SMS-Code of Conduct (2003) was only updated following pressure from public authorities. In 2008 and 2010, this Code was adjusted to tackle (unfair) practices many consumers were complaining of, for example, them not being aware of subscribing to a SMS premium service, ignoring the costs and finding it difficult to unsubscribe from the service. ${ }^{82}$ To spur traders to integrate the UCPD standard into their codes, national regulators and enforcement bodies have different more or less intrusive methods at their disposal. The directive leaves the choice of those methods to the MS.

\subsubsection{The 'soft' approach}

National enforcement authorities can stimulate the compliance of codes with the UCPD. They can for example provide guidance ${ }^{83}$ or publicly endorse fair codes. Statutory endorsement schemes do not exist in the Netherlands or in France but are common in the UK. ${ }^{84}$ A carrot approach such as the granting of a public approval to codes of conduct is not provided for by the UCPD. One of the core criteria for consumer codes of practice to obtain OFT approval is compliance with the UCPD standards as far as the advertising and marketing rules are concerned. ${ }^{85}$ The British system of (voluntary) approval of codes of conduct has however not been boosted by the CPR. The expected spur to obtain OFT approval ${ }^{86}$ did not occur. ${ }^{87}$ Although OFT approval not conferring a shield may have decreased its appeal to traders, the very relative success of the OFT scheme may above all be explained by its long and relatively labour-intensive application process. The scheme has been criticised for being bureaucratic and inflexible and evidence of strong consumer recognition of - and trust in - the OFT approval logo is limited. ${ }^{88}$ Meanwhile, the OFT scheme has lost government support and its public funding is set to cease. ${ }^{89}$ The Government points at the fact that there are many other public accreditation

\footnotetext{
$78 \mathrm{Cf}$. the Code déontologique du e-commerce et de la vente à distance that has recently been enacted by the FEVAD.

79 BAC, above n. 52, at $\S 3.5$.

80 Misleading Advertising on the internet, above n. 62, at 17.

81 FEDMA is currently still revising the Code of Conduct for E-Commerce and Interactive Marketing.

82 The adjustments did however not suffice according to the Dutch Ministry of Economic Affairs since vulnerable consumers would still not get enough protection.

83 The OFT has for example published guidance for second-hand car dealers on compliance with the CPR 2008.

${ }^{84}$ Alternatives to the OFT scheme are the TrustMark scheme of the Department for Business, Innovation and Skills (building repair, maintenance and improvement sector) and the local authority assured trader schemes run by local Trading Standards services.

85 OFT, Consumer Codes Approval Scheme - Core Criteria and Guidance (March 2008), at 15.

86 Twigg-Flesner e.a., above n. 15 , at 8 (§ 2.17).

87 To date, 10 codes of practice have been approved with a further 10 working towards approval. Department for Business, Innovation \& Skills (BIS), Consumer landscape review: impact assessment (June 2011), at 13 .

88 BIS, above n. 87 , at 28 .

89 The UK government has decided to invite the Trading Standards Institute to establish a successor to the Approval Scheme from April 2013 on a self-funding basis. The potential costs associated with lack of consumer confidence due to removal of consumer code approval scheme are expected to be negligible: BIS, above n. 87, at 2. Under the UK Government's proposals to create a single Competition and Markets Authority (CMA), the OFT will be merged into the new body which will have a principal focus on competition and markets. A continuing role in consumer codes approval does not seem appropriate for the
} 
systems, such as TrustMark and local authority Buy with Confidence. There is a risk however that alternative bodies may give approval more readily than the OFT, thereby weakening consumer protection.

\subsubsection{The 'hard' approach}

If a soft approach proves ineffective, a more drastic line may be needed. One obvious strategy would be to threaten the sector failing to adjust its code with formal regulation. The Dutch SMS premium services sector has constantly been facing government's threats to legislate. The SMS code and its adjustments have however not prevented the Dutch legislator to tighten the legal regulations for SMS services in 2011. MS, though, do not dispose of a great margin of manoeuvre in view of the maximum harmonisation scope of the UCPD. ${ }^{90}$ They are not allowed to prohibit practices that are not listed in the directive's first Annex. ${ }^{91}$

If a code offers less protection than the UCPD by promoting non-compliance with legal requirements, a MS may also decide to enable a legal action against the code owner (Article 11(1)(b) UCPD). If a MS waives this possibility, the trader who makes use of the unfair practice described in or promoted by the code is the only one who can be held liable. Such a legal facility was created both in the Netherlands (Article 305d(2) of Book 3 of the Dutch Civil Code) ${ }^{92}$ and in the UK (Reg. 4) - not in France - but without a potentially discouraging criminal offence being attached to it. Any enforcement action, if needed, will be taken through the civil route. Enforcers are likely to rely on this prohibition where the promotion takes the form of a statement in the code of conduct and altering the code of conduct looks like a more effective method of dealing with the unfair practice than taking action against any individual trader or traders who are engaging in the practice. No actions have been brought against unfair code owners as of today.

\subsection{Enforceable Codes of Conduct}

\subsubsection{Private enforcement}

To raise the level of consumer protection, 'fair' codes of conduct need to be compulsory for their members and to be enforceable through independent, non-legal, both preventive (guidelines, certification ${ }^{93}$ ) and oppressive instruments. Some kind of consumer complaint scheme coupled to sanctions for non-compliance and/or prescriptions for redress plays an essential role in enforcing codes of conduct. At the European level, between the purely voluntary schemes and the genuinely compulsory schemes, there are lots of mixed schemes. ${ }^{94}$ The same counts for the national level.

In France most schemes are purely voluntary. One of the few independent boards upholding breaches of codes of conduct is the Jury de Déontologie Publicitaire (JDP) which handles complaints regarding advertising since 2008. Advertising self-regulatory bodies have mainly focused on the ex-ante control of advertisements (before their publication). The JDP is meant to strengthen the ex-post control. Another French independent complaint scheme based upon a code is the Commission Paritaire de

CMA: BIS, Empowering and Protecting Consumers: Consultation on institutional changes for provision of consumer information, advice, education, advocacy and enforcement (June 2011), at 8 .

90 Cf. W.H. van Boom, 'Wetsvoorstel doorverkoop toegangskaarten: nuttig en nodig?', Tijdschrift voor Consumentenrecht en Handelspraktijken 5, at 183 (2011) (footnote 37).

91 C-261/07 and C-299/07, VTB-VAB and Galatea, [2009] ECR I-2949.

92 Amendments made to the enforcement mechanism for the UCPD however seem to prevent administrative authorities from getting access to this facility.

${ }_{93}$ Since 2009, all Thuiswinkel.org members (a Dutch distance selling association) applying the Thuiswinkel Code of Conduct are obliged to get certified every year.

${ }_{94}$ P. van der Zeijden and R. van der Horst, Self-Regulation Practices in SANCO Policy Areas, Final Report (2008), at 20-21. 
Médiation de la Vente Directe. In the UK, most codes of conduct are enforced through consumer complaint schemes. The OFT approved codes of conducts all have userfriendly and prompt procedures for dealing with customer complaints and bestow access to low cost, independent advice to resolve disputes. Some have independent redress schemes (e.g. the Travel Association [ABTA]). In the Netherlands, the twosided GTC are systematically coupled to bilateral dispute committees, which solve individual disputes related to the compliance with the GTC.

\subsubsection{Public enforcement}

The UCPD stimulates public enforcement bodies acting as the 'enforcer of last resort' (Article 10) ${ }^{95}$ There are two reasons why public enforcement is necessary and selfregulatory systems cannot substitute legal enforcement.

First, codes of conduct do not always contain appropriate and effective mechanisms for monitoring and enforcing compliance. A code's strongest sanction is to end membership and few code sponsors have pro-active compliance monitoring schemes. The enforceability of private regulation remains its weaker component since it proves difficult for code owners to act against their own members. Enforcement possibilities working independently of any influence from their members are often lacking. Even if an independent redress mechanism is available, public authorities may see the need to intervene to force compliance with a code of conduct and following on from this, with the directive's standards. The OFT for example urged the ABTA to remind its members that their code of conduct, which is binding on all members, requires all fixed nonoptional costs to be included in the basic advertised prices of their holidays.$^{96}$ Individual dispute resolution schemes are not apt to cope with unfair practices that only marginally affect individual consumers - who will then refrain from employing those schemes. Neither are those schemes adapted to deal with large-scale infringements.

Second, the interpretation of the UCPD by self-regulatory bodies may not always be the right one. Private bodies are interpreting and enforcing the UCPD rules, that have been integrated into their codes. ${ }^{97}$ In the UK there has been criticism on code owners acting as primary enforcer because their interpretation of the codes was not consumerfriendly enough. ${ }^{98}$ The Dutch public enforcers have very clearly stressed that decisions by private enforcers are not determinative as to the fairness of a commercial practice. ${ }^{99}$

\subsubsection{Misleading claims to abide by a code}

Article 6(2)(b) UCPD is meant to strengthen self-regulatory practice by providing public authorities with a tool to enforce code compliance. In the Netherlands, this Article was transposed into Article 193c(2)(b) of Book 6 of the Civil Code. This Article, it is fair to say, has secured the CA's position as enforcer of last resort in the past years. This public body actively cracks down on misleading claims to abide by a code of conduct ${ }^{100}$ or twosided GTC (which are considered to be codes of conduct). ${ }^{101}$ The CA has taken a firm

\footnotetext{
95 Green paper, above n. 4, at 14.

$96<$ www.oft.gov.uk/OFTwork/consultations/self-regulation> (last visited on 18 September 2012).

97 Self-regulatory bodies may also enforce UCPD rules not laid down in a code but applying to the practice the consumer is complaining about.

98 The UK ASA has been criticised for deciding that Vodafone's 'Unlimited'-ads didn't violate their CAP Code because their broadband ads 'made clear that a fair-use policy applied to the service and the level at which the allowance was set': <www.consumingexperience.com/2008/10/unfair-commercial-practicesconsumer.html $>$ (last visited on 18 September 2012).

99 CFI Rotterdam 19 April 2012, LJN BW3358, at § 23.3.

100 Celldorado (case 510, 17 June 2010) and Smart Media Services (case 220, 26 January 2009) were fined for breaching the SMS-Code of Conduct. Garant-o-Matic (a mail-order firm) got collared for breaching the Promotional Lottery Code (case 544, 21 September 2010). Greenchoice (case 661, 27 May 2011) and the Nederlandse Energie Maatschappij (case 527, 6 September 2010) were fined for not complying with the Consumer and Energy Supplier-Code.

101 In Keukenkampioen and Keukenconcurrent (cases 426 and 427, 19 November 2009) followed by CFI
} 
line on the enforcement of codes of conduct since the UCPD was implemented. It has for example imposed a $€ 1.2$ million fine on a SMS services provider who kept pushing the boundaries of the code it had signed up to. ${ }^{102}$

The French Article implementing the 'misleading practice' - Article L 1211 Consumer Code - does not refer to the misleading claim to live up to a code of conduct. The reason why the directive provision has been left aside is not clear as it was not explicitly motivated during the transposition process. Maybe the legislator figured Article L 121-1 would cover the practice described in Article 6(2)(b). The case of French price comparison website proves him correct (cf. paragraph 3.2). I however doubt whether those Articles would achieve the clarity and precision needed to meet the requirement of legal certainty the CJEU expects implementing provisions to fulfill. ${ }^{103}$ Another reason why the legislator ignored Article 6(2)(b) might be the limited role codes of conduct play in French consumer protection.

Regulation 5(3)(b) transposes Article 6(2)(b) in the UK. Breaching this provision does not form a criminal offence according to Regulation 9, once again to not discourage self-regulation. Prior to the UCPD, the practice consisting of a misleading claim to abide by a code already fell within the ambit of the Control of Misleading Advertisements Regulations 1988 (CMAR 1988). ${ }^{104}$ Such practices were also caught by the Trade Description Act 1968 (TDA 1968). A motor dealer was found to have breached s. 14 TDA 1968 for falsely claiming that he complied with the Motor Industry Code of Practice. ${ }^{105}$ The new Regulation has however not yet been applied and tested before court. The OFT will generally seek to obtain compliance by education, giving advice and guidance in the first instance. ${ }^{106} \mathrm{~A}$ close cooperation with the public enforcement body helps traders escape administrative and judicial scrutiny.

\subsubsection{Filters}

The effectiveness of well-functioning private enforcement mechanisms eventually depends on official bodies handing them over some responsibility. The enforceability of codes of conduct can be enhanced by introducing filters that encourage the use of complaint schemes run by code owners. Article 11(1) UCPD enables MS to decide whether the courts or administrative authorities are allowed to require prior referral to other established means of dealing with complaints (including code complaints schemes) before pursuing legal remedies. ${ }^{107}$

Public enforcers in the UK advocate compliance by the most appropriate means, in line with their enforcement policies, priorities and consistent with available resources. ${ }^{108}$ Civil and criminal enforcement come the very last in the order of priority. Relationships have been developed with 'established means' to resolve breaches of the CPR. The OFT could already require prior referral to code complaints schemes in cases of misleading advertising. ${ }^{109}$ The CPR have extended the scope for the use of 'established means' to

\footnotetext{
Rotterdam 19 January 2010, LJN BK9796 \& BK9798 and CFI Rotterdam 14 April 2011, LJN BQ1281 two kitchen selling companies - both members of the Living Central Trade Association (CBW) - were sentenced for infringing on the CBW's bilateral GTC. Grando Retail on its turn has undertaken to stop acting in breach of the CBW-code (cases 317 and 318).

102 Celldorado (case 510, 17 June 2010). The CA and the AFM are entitled to sanction and to fine traders breaching the UCPD rules.

103 Case C-144/99. Commission v. Netherlands [2001] ECR I-3541.

104 Consultation on implementing the EU Directive on Unfair Commercial Practices and Amending Existing Consumer Legislation (December 2005), at 34.

105 V.G. Vehicles (Telford) Ltd [1981] 89 Monthly Review 91.

106 OFT Guidance on the UK Regulations (May 2008) implementing the Unfair Commercial Practices Directive, at 51 .

107 Courts and administrative authorities cannot be forced to refer a matter to a code complaint scheme.

108 OFT Guidance, above n. 106, at 51.

109 The CMAR 1988 empowers the Director General of Fair Trading (now the OFT) to require that a reasonable opportunity has been allowed for self-regulatory bodies to deal with the complaint in question: Reg. 4(3)(3).
} 
all behaviours covered by the directive (Reg. 19(4)). ${ }^{110}$ Public bodies and consumer organisations (e.g. Citizens Advice) actively promote extra-judicial complaint handling and direct individual consumers to alternative dispute resolution (ADR) where this is available.

In the Netherlands, referral is the expected norm too. ${ }^{111}$ The cooperation between different established means is being formally addressed by means of so-called samenwerkingsprotocolen. The Dutch Consumer Protection Enforcement Act allows for such cooperation protocols to be agreed upon by the administrative authorities responsible for the enforcement of the UCPD and self-regulatory bodies. A protocol regulates among other things the exchange of information and the cross-referrals between the public and the private enforcement body. In the field of advertising, the CA yields its enforcement task to the Stichting Reclame Code (SRC) according to such a protocol. A samenwerkingsprotocol has also been signed between the CA and the aforementioned bilateral dispute committees. Those committees handle individual complaints arising in the many sectors making use of bipartisan GTC whilst the CA tackles practices violating collective consumer interests.

No formal 'filters' or cooperation agreements exist in France. Even if a selfregulatory compliance mechanism has been set into motion, the administrative agency may decide to simultaneously and independently undertake an action of its own. ${ }^{112}$ The DGCCRF leaves it to the consumer where to file a complaint and does not specially recommend ADR. Independent $\mathrm{B} 2 \mathrm{C}$ mediation and conciliation are steadily turning into established means of complaint but these forms of ADR often result from public regulation. Privately initiated mediation and conciliation are generally not coupled to a code of conduct. The consumer has found his way to the JDP ${ }^{113}$ but remains free either to file his complaint at a public agency or to go to court instead. ${ }^{114}$ As concerns judicial recourse by (groups of) consumers or professionals, courts in all three scrutinised MS are fully free to not demand referral and they always hear the matter directly.

\subsection{The Enforcement of the UCPD by Codes of Conduct: A Limited Contribution to Consumer Protection}

In MS with a tradition of self-regulation not much has changed after the UCPD was enacted. In the UK and in the Netherlands, self-regulation assists in raising the level of consumer protection. Free complaints schemes are very effective in handling individual complaints. Responsibility is being handed over to those private bodies that have effective (fair) codes of conduct. Self-regulation is however not always successful and the Dutch CA plays a substantial role in enforcing compliance with codes of conduct and two-sided GTC. Article 6(2)(b) provides a useful tool to this end. The long termeffects of the far-reaching public control on self-regulation are however not clear: it may either raise or lower the attractiveness of self-regulation.

The UCPD, however, did not 'lift' self-regulation. The importance of national advertising self-regulatory bodies for example still strongly differs from one MS to another. ${ }^{115}$ The directive also fell short of evidently increasing the number of self-

\footnotetext{
110 The OFT also held a public consultation on a draft set of principles that it proposed to apply when working with its partners to maximise compliance with the CPR: <http://www.oft.gov.uk/shared_oft/ consultations/oft1043con.pdf> and <www.oft.gov.uk/shared_oft/consultations/OFT1043resp.pdf> (last visited on 18 September 2012).

111 The need for administrative bodies to show some restraint while self-regulatory solutions are sought was emphasised during the directive's transposition process: Minutes of the Upper House 2008/09, No 1, at 31. The CA undertook enforcement actions in the Celldorado-case only after self-regulatory measures had failed: BAC, above n. 52, at $\S 5.18$.

112 Both the JDP and the DGCCRF tackled the misleading practices used by the Repertoire des sociétiés et des indépendants (RSI): CA Paris 8 November 2011, No 11/16050 and JDP decision of 8 July $2011<\mathrm{http} / /$ www.jdp-pub.org/RSI,230.html> (last visited on 18 September 2012).

113 As appears from the report Un an d'activité en chiffres $<\mathrm{http}$ ://www.jdp-pub.org/Statistiques, 103.html> (last visited on 18 September 2012).

${ }_{114}$ The DGCCRF only has had the power to enforce the prohibition on misleading advertising since 2007.

115 Misleading Advertising on the internet, above n. 62, at 15.
} 
regulatory initiatives in other areas than the already harmonised fields of advertising and e-commerce. ${ }^{116}$ Many existing codes have integrated the UCPD and have been geared towards addressing new developments (new media) and complaints (SMS services providers), but overall few new codes of conduct were devised since the directive took effect, even in those MS where self-regulation is well-developed. The reliance on codes is still very much confined to advertising.

With regard to minor violations of the UCPD a report commissioned by the EP concludes it could be an option to envisage a more developed cooperation between advertising self-regulatory bodies and enforcement bodies in the EU. ${ }^{117}$ Self-regulatory bodies could help prevent misleading commercial practices in the first place by promoting compliance with the codes and by issuing guidelines. ${ }^{118}$ They could also concern themselves with 'easier' cases, helping national enforcement authorities to save time and costs. ${ }^{119}$ The interaction between private and public bodies is working rather well in those countries where this interaction has been institutionalised (e.g. the UK and the Netherlands).

Still, consumer organisations have little faith in the benefits of self-regulation in terms of the enforcement of the UCPD. According to the Bureau Européen des Unions de Consommateurs (BEUC) 'enforcement under a self-regulation approach should be avoided in the field of unfair commercial practices'. ${ }^{120}$ Paragraph 6.3 elaborates on the author's disagreement with this statement.

\section{Self-regulation's Contribution to Fulfilling the Harmonisation Objective}

\subsection{Converging National Private Standards of Fairness}

Not all codes integrate the UCPD standards or flesh them out (cf. paragraph 4.3.1). But if they do so, codes tend to focus on different types of commitments as practices in a same sector differ across markets and countries. Code owners are moreover not formally required to confine themselves to the legal standards set by the UCPD and may offer more protection than the directive. The UCPD is a minimum harmonising instrument as regards codes of conduct. Codes of conduct varying from one MS to another, therefore, contribute to differentiating the fairness appraisal - if they were to impact this appraisal. This, however, turns out not to be the case very often (cf. paragraph 3).

The level of convergence can be measured by comparing codes of conduct in a same sector of activity across the EU. In the car sector, the Dutch two-sided BOVAG-terms can for instance be collated with the Vehicle Builders \& Repairers Association-Code (VBRA) in the UK. There are differences in the type of commitments traders made to enable the consumer to make an informed decision. The VBRA stipulates that the customer should be advised that if required, any displaced parts can be made available for inspection or returned with the exception of those parts required for exchange or warranty. Where parts are required to be fitted, the customer should be provided with a clear explanation for the need for replacement. According to the BOVAG-terms parts that have been replaced may be reclaimed by the customer at the time the order to repair the car was placed. The GTC entailing the commitments reached by the Dutch car traders do not mention any obligation to inform the consumer about his rights.

In the field of direct selling, the Consumer Code of Practice of the UK Direct Selling Association can be compared with the French Code Ethique de la Vente Directe and the two-sided GTC of the Dutch Vereniging Directe Verkoop. The trader's response to a complaint should occur within respectively 10,21 and 14 working days. The British

\footnotetext{
16 V. Valce, 'Codes of conduct and unfair commercial practices', Bancaria 1 (2012), at 95-97: As regards the banking sector 'the legislative indications in terms of self-regulation have remained largely unheeded and typical features of the codes of conduct have not been sufficiently exploited'.

117 State of play, above n. 63, at 18.

118 State of play, above n. 63, at 21.

119 Misleading Advertising on the internet, above n. 62, at 17.

120 Answer to the European Commission's questionnaire on the application of Directive 2005/29/EC, at 18 <www.beuc.org/custom/2011-09895-01-E.pdf> (last visited on 18 September 2012).
} 
Code is much longer and more detailed than its French and Dutch counterparts. This code, to quote but one example, provides for concrete guidelines as to the time of day an appointment should be made ( 9 a.m. to 8 p.m.) and what can be regarded as a visit of reasonable length in the case of a straightforward product (max 30 minutes) and a party plan visit (max 2 hours).

Codes of conduct include many general clauses and open-textured commitments. Given the similar general wording of most advertising codes - which oblige their members to refrain from using misleading practices - interpretation differences may arise among self-regulatory bodies from different MS. ${ }^{121}$ The SRC has for example opted for a consumer-friendly interpretation of the directive provisions on misleading advertising ${ }^{122}$ whereas the ASA has been reproached a lenient approach towards traders. ${ }^{123}$ What is more, the main focus of self-regulatory codes in the field of advertising seems to be on nationally tainted issues of 'taste and decency', which are not addressed by the UCPD (recital 7) but nonetheless influence the fairness assessment by private bodies. Finally, the fact that self-regulatory bodies have no access to preliminary procedures also hinders harmonisation.

\subsection{EU-wide Codes of Conduct}

Private regulation has contributed to European legal integration, mainly in the fields of advertising (EASA), direct marketing (FEDMA), timeshare (OTE), direct selling (FEDSA) and distance selling (EMOTA). ${ }^{124}$ The UCPD however hardly impacted this contribution and EU-wide self-regulation of other commercial practices and sectors is still scarce. It goes without saying that the differences in national laws keep hampering the development of EU-wide codes of conduct.

In its Green Paper the Commission stated that the option for EU-wide self-regulation could only work if non-compliance with a voluntary code would define as either a misleading or unfair trading practice and if the scope of the general duty would apply to trade associations and other organisations that make recommendations on trading practices and draw up codes. ${ }^{125}$ Although the reinforcement of the responsibility of code owners in developing codes was left to the MS, the directive made voluntary commitments legally binding. Article 6(2)(b), however, has not yet fostered self-regulation at the European level. The technique of creating 'safe harbours' would have been a greater stimulus for self-regulation at EU-level given that EU-wide codes of conduct could have effectively helped creating practicable and attractive 'safe harbours'. ${ }^{126}$

\section{Amendment Proposals}

\subsection{Optimising the Interplay between Codes of Conduct and the UCPD}

The UCPD aims at improving the functioning of the internal market by banning unfair commercial practices and by raising consumer confidence. For legal-cultural reasons mainly, codes do not contribute much to achieving the UCPD's twofold goal of consumer protection and harmonisation.

\footnotetext{
121 Interpretation divergences regarding the content of codes also occur between self-regulatory bodies and administrative authorities as shows the Celldorado-case, above n. 100.

${ }_{122}$ The misleading assessment is even stricter than before the UCPD was integrated into the Reclame Code as show the decisions of the Dutch Advertising Code Commission of 18 March 2008, No 08.0050 and 23 April 2008, No 08.0084.

${ }^{123}<$ www.consumingexperience.com/2008/10/unfair-commercial-practices-consumer.html> (last visited on 18 September 2012).

124 Van der Zeijden and Van der Horst (2008), above n. 94, at 19-20.

125 Green paper, above n. 4, at 14.

126 Collins (2004), above n. 11, at 30.
} 
The directive has not sufficiently encouraged such a contribution though. ${ }^{127}$ At its publication, it was stated that the UCPD would have a counterproductive effect on self-regulation and that self-regulation should operate as first recourse (cf. paragraph 2.5). The UCPD regards self-regulation as an optional add-on and was criticised for not acknowledging the existence of effective and reliable regimes prior to the directive. ${ }^{128}$ The functioning of effective and reliable regimes has however not been impaired by the UCPD, which has been a welcome addition to the consumer protection arsenal, filling in the gaps left by existing law and failing self-regulation.

In the UK and the Netherlands, codes of conduct - not surprisingly - effectively add to the level of consumer protection by impacting either the interpretation or the enforcement of the UCPD standards. The case of the Dutch SMS-Code however shows the necessity for public enforcement of the UCPD. But from the way codes have been fleshing out the directive's standards in the Netherlands appears that the balancing of consumers' and traders' interests might need further consideration. The purpose of this paper is to ascertain how more co-regulation in the sense of a further integration of codes of conduct into the UCPD could serve both its consumer protection and harmonisation goals and strike the delicate balance between consumers' and traders' interests. ${ }^{129}$ Which way of dealing with codes of conduct would, based on the experience of the past years, at the same time lead to more consumer protection and harmonisation without losing sight of the traders' interests? It goes without saying that codes of conduct would only lead to harmonisation provided national self-regulatory bodies and public authorities and courts cooperate closely. ${ }^{130}$

\subsection{Codes of Conduct and the Interpretation of the UCPD Standards}

The fact that (mostly non-)compliance with a code of conduct helps define the fairness of practice is somehow tricky given the open-textured nature of many code provisions. It will not always be clear whether a specific practice infringes on a code and consequently breaches the legal standard. The public body's point of reference should be the code owner's interpretation of the broadly worded code provision (cf. paragraph 6.3). The public body should reason a decision to depart from this interpretation. If such guidance is not available, the following 'rules' should apply. An ambiguous provision would have to be construed against the professional insofar as consumer organisations have not been involved into its drafting. ${ }^{131}$ This contra-proferentem rule could provide an incentive for trade associations to engage in a proper mutual dialogue with consumer associations and to draft codes that are as clear and explicit as possible. 'Bilateral' codes should be construed objectively by explicitly balancing the interests of both parties.

To increase the appeal of codes of conduct, a presumption of conformity should be put into place for concrete and firm commitments, provided they have been endorsed by a public enforcement authority. ${ }^{132}$ Such an endorsement should only be given on the condition that consumers have been invited to participate into the self-regulatory

\footnotetext{
127 At the national level the UCPD has not succeeded in giving self-regulation a more prominent role in countries where there is no tradition of self-regulation. 'Those countries which lack a history of using soft law techniques are only likely to take it seriously if it forms part of the legal regime': Howells (2004), above n. 31 , at 125 .

128 Above n. 27

129 With a view to consumers' interests more co-regulation in the sense of a greater involvement of consumer organisations is equally needed.

130 When assessing whether a trader acts in breach of an EU-wide code national enforcement bodies would need to cooperate within the Enforcement Network created by Regulation (EC) No 2006/2004. General clauses in a European Code may hamper harmonisation insofar as the national authorities acting as 'last enforcers' have different interpretations of the commitments that were reached.

${ }_{131}$ In analogy with Article 5 of Directive 93/13/EEC on unfair terms in consumer contracts (OJ 1993 L 95/29).

${ }_{132}$ The prior approval by a relevant public body warrants that codes comply with legal standards: Collins (2004), above n. 11, at 31 .
} 
process. ${ }^{133}$ This presumption would offer determinate guidance and legal certainty to traders and foster the creation of new codes of conduct. It should however only be introduced insofar as the commitments are put in sufficiently clear and firm wordings. This may lead code owners to flesh out the code's open-textured provisions and to sharpen their commitments. The use of general clauses in national codes hinders harmonisation as much as the use of such clauses in the UCPD itself. Of course there will be a good deal of debate about just how concrete and firm a commitment is, but guidance from the Commission or the CJEU may help draw the line.

Codes offering more protection than the directive (e.g. entailing stricter information duties) should only bind those traders who adhere to them. A trader who has not signed up to a code he fails to comply with should not be presumed to act in breach with the requirement of professional diligence. More prescriptive or restrictive rules may only apply to those who subscribed to them. Enforcement bodies and courts should however explicitly ascertain whether the level of protection afforded by the code outreaches the UCPD standard. Enforcement authorities should keep in mind that the UCPD is a minimum harmonising instrument as regards codes of conduct.

In the published decisions and jurisprudence where codes helped fleshing out the UCPD norms, factors attesting of a code's legitimacy - its endorsement, the consultation with stakeholders or the wide support for a code - did not play any role of importance. The legitimacy of a code as a benchmark of fairness would however increase if such aspects were explicitly taken into consideration.

\subsection{Codes of Conduct and the Enforcement of the UCPD Standards}

The directive should stimulate self-regulation by increasing its role in the enforcement of its standards. The consumers' interests are secured by codes of conduct that integrate the UCPD and are enforced through easy accessible dispute settlement procedures and pro-active compliance mechanisms that act as a first port of call. The establishment of such procedures and mechanisms should be encouraged by formal means such as referral schemes applicable to both agencies and courts. Consumers filing their complaints at a local court could be incited towards opting for ADR instead, if this is available. ${ }^{134}$ The recent proposal for a Directive on consumer ADR acknowledges the need for complementary means of dispute settlement. ${ }^{135}$

Public bodies should help increase the legitimacy of high-quality private enforcement decisions pertaining to the directive's standards, by expressly acknowledging those decisions. The review of a commercial practice under a UCPD standard, which is literally transposed into a code (e.g. the misleading clause in an advertising code) by an established independent means, should also benefit from a 'presumption of conformity'. When testing the same practice against the analogous statutory general clause, public bodies should refer to this clause's interpretation by the private enforcement body and reason a decision to depart from this interpretation. ${ }^{136} \mathrm{~A}$ decision by a private enforcement means should in principle be upheld by a court unless the claimant proves the private ruling clearly misinterprets the directive. A clear misinterpretation of a general clause is fairly unlikely (but nonetheless plausible).

Code owners need to be held responsible for the conformity of their codes - Article 11(2) should not leave this for the MS to decide. The responsibility of their actions should be reinforced. Public authorities need to play a role on the background, controlling the fairness and enforcement of the codes. The extent to which enforcement authorities

\footnotetext{
133 Both aspects of co-regulation are then combined: a further integration of codes would imply more consumer participation.

134 Needless to say that those schemes would need to warrant free access to justice.

135 Proposal for a Directive of the European Parliament and of the Council on alternative dispute resolution for consumer disputes and amending Regulation (EC) No. 2006/2004 and Directive 2009/22/EC (Directive on consumer ADR).

136 Cf. Cafaggi (2011), above n. 2, at 122 puts forward the 'harmonise or explain'-principle according to which a national regulator has duty to explain why, in its interpretation of professional diligence, it deviates from the common interpretation by self-regulatory bodies.
} 
have to be involved into the process of self-regulation should however depend on the readiness of private actors to cooperate and to integrate legal standards. In first instance public bodies should confine their involvement to facilitating and rewarding private initiatives.

\subsection{European Codes}

Finally, the directive should explicitly encourage the drawing of EU-wide codes like the E-commerce Directive does. EU-wide codes can contribute to harmonisation as long as they:

- are widely supported and preferably publicly endorsed by the Commission,

- are rigorously enforced - both by code owners and by (closely cooperating ${ }^{137}$ public authorities, and

- play an important role in concretising the directive's general clauses.

Consumer organisations should participate in the development of EU-wide codes. There is however a lack of institutional mechanisms that could help establish a dialogue between consumers and traders at EU-level. The new consumer programme 2014- 2020 projects to offer grants for action to Union-wide bodies for the development of codes of conduct but does unfortunately not intend to develop such mechanisms. ${ }^{138}$

\footnotetext{
137 When assessing whether a trader acts in breach of an EU-wide code national enforcement bodies would need to cooperate within the Enforcement Network created by Regulation (EC) No 2006/2004. The use of general clauses in European codes of conduct may hamper harmonisation as national authorities might have different interpretations of the commitments that were reached.

138 Proposal for a Regulation of the European Parliament and of the Council on a consumer programme 2014-2020 COM (2011) 707 final, at 15.
} 